UDC 557.15

\title{
ANTIOXIDANT DEFENSE OF RAT ORGANISM AT LONG-TERM PER ORAL INJECTION OF TAURINE
}

\author{
R. D. Ostapivi,2, V. V. Manko ${ }^{1}$ \\ ${ }^{1}$ Ivan Franko National University of Lviv, 4, Hrushevskyi St., Lviv 79005, Ukraine \\ ${ }^{2} S S R C l$ of Veterinary Medicinal Products and Feed Additives \\ 11, Donetska St., Lviv 79019, Ukraine \\ e-mail:vvmanko@Inu.edu.ua
}

\begin{abstract}
Aim of this work was to study the activity of antioxidant defense enzymatic link, glucose-6-phosphate dehydrogenase activity and content of TBA-active products at long term per oral injection of taurine. Male Wistar rats (4.5 months old and with body weight 190-220 g) were used in the experiments. Animals were randomly divided into three groups: one control group and two experimental groups. During 28 days period, animals were daily injected in esophagus: control group - drinking water, experimental group I and II - solution of taurine (40 and $100 \mathrm{mg} / \mathrm{kg}$ of body weight, respectively). On the $29^{\text {th }}$ day, the animals were decapitated under light chloroform anesthesia, and liver, brain, testes and thigh muscle were extirpated. The tissues were homogenized and then centrifuged for $15 \mathrm{~min}$ at $1,000 \mathrm{~g}$. In supernatant, the activities of superoxide dismutase, glutathione peroxidase, catalase and glucose-6-phosphate dehydrogenase, and content of TBA-active products were measured. Ratio of antioxidant enzymes activity to TBA-active products content (AOD/TBA) was calculated. It was determined, that in rat liver of $I^{\text {st }}$ experimental group, the activity of all antioxidant defense enzymes, glucose-6-phosphate dehydrogenase and content of TBA-active products increased. Under these conditions, the resistance of this tissue to oxygen free radicals, and AOD/ TBA ratio also increases. In the II $^{\text {nd }}$ experimental group, the superoxide dismutase activity was similar to control values, but other indices remained higher than in control group. Similar trend was observed in the thigh muscle of both experimental groups, where it was found that, activity of antioxidant enzymes and glucose-6-phosphate dehydrogenase increased, and the amount of lipid peroxidation products also elevated. At the same time, the AOD/TBA ratio was the highest in animals of the II ${ }^{\text {nd }}$ experimental group. In testes of animals of the $\mathrm{I}^{\text {ts }}$ experimental group, an increase in the glutathione peroxidase activity was established, and the content of TBA-active products was the highest among three groups. A rise in content of TBA-active products caused a decrease in AOD/TBA ratio in more than 4 times. In the II $^{\text {nd }}$ experimental group, it was found that the increase of antioxidant enzymatic activity and decrease of content of TBA-active products, compared to the $I^{\text {st }}$ experimental group, caused an increase in AOD/TBA ratio. In brain tissue, glutathione peroxidase and catalase activity increased at a constant content of peroxidation products. This caused an increase in AOD/TBA ratio, that indicates growth
\end{abstract}

ISSN 1996-4536 (print) • ISSN 2311-0783 (on-line) • Біологічні Студії / Studia Biologica • 2015 • Том 9/№2 • C. 59-70 
of resistance to oxygen free radicals. Thus, the effect of long term per oral injection of taurine on the enzymatic link of antioxidant defense is tissue- and dose-dependent.

Keywords: taurine, superoxide dismutase, glutathione peroxidase, catalase, TBA-active products, liver, thigh muscle, testes, brain.

\section{INTRODUCTION}

Free oxygen radicals that are produced in oxidase reactions and mitochondrial electron transport chain. They are involved in many metabolism processes, in particular, membrane alteration, capacitation and phagocytosis [16]. However, at high concentrations of free oxygen radicals cell, and organelle membranes are damaged, and homeostasis is violated that can lead to cell death [10].

Antioxidant defense system is a complex of enzymes and organic compounds, task of which is to maintain the level of free oxygen radicals in physiological limits [9]. Key enzymes of antioxidant defense are superoxide dismutase that transforms superoxide anion to hydrogen peroxide which is dissolved by glutathione peroxidase or/and catalase [2]. Glucose-6-phosphate dehydrogenase is one of NADP-dependent enzymes that provides $\mathrm{NADPH}^{+}$to restore glutathione. Nonenzymatic antioxidant defense system includes glutathione, vitamin E, ascorbic acid, and taurine [9].

Taurine is a free sulphur containing amino acid that plays an important role in maintaining cell antioxidant defense. Taurine was long considered as inert compound, a oxidation product of hypotaurine, having no influence on the activity of antioxidant defense enzymes and content of free oxygen radicals [1]. However, it was determined, that incubation of brain neurons with taurine caused an increase of activity of antioxidant defense enzymes and glutathione content [16]. Besides, per oral treatment with taurine under the conditions of diabetes of second type, caused an increase in the activity of antioxidant defense enzymes and decrease in glucose concentration in blood [23]. Bull semen incubation with physiological concentrations of taurine increased activity of superoxide dismutase and catalase that resulted in spermatozoa survival increase [11]. Taurine maintained antioxidant defense activity on certain level, that was evidenced by at decrease in antioxidant defense enzymes and increase in TBA-active products level at taurine depletion in rat organism [22]. Fifteen days administration of taurine in $1 \%$ water activity of solution, instead of drinking water, caused an increase of TBA-active products concentration in rat's liver [16]. This means that increase of taurine content may have a negative impact on liver metabolism, though in literature it is positioned as an antioxidant and detoxicant. Thus, influence of taurine on antioxidant defense system is not clearly understood. Also, it is necessary to mention that liver, brain, testes and muscle are organs in which taurine is present in high concentrations and it plays an important role in production of ATP [24] and in maintaining antioxidant defence [23]. Therefore, mechanisms of long-term oral injection of taurine affects the production and utilization of oxygen free radicals should be determined.

\section{MATERIALS AND METHODS}

Male Wistar rats were used in the experiments. The rats were 4.5 months old and with body weight $190-220 \mathrm{~g}$ at the beginning of the experiments. Animals were randomly divided into three groups: one control group and two experimental groups. During a 28 day period, animals were daily injected in esophagus: control group - drinking

ISSN 1996-4536 (print) • ISSN 2311-0783 (on-line) • Біологічні Студії / Studia Biologica • 2015 • Том 9/№2 • C. 59-70 
water, group I and II-solution of taurine (40 and $100 \mathrm{mg} / \mathrm{kg}$ of body weight, respectively). On $29^{\text {th }}$ day, the animals were decapitated under light chloroform anesthesia, and liver, brain, testis and thigh muscle were extirpated. All animal experiments were performed in accordance with European Convention for the Protection of Vertebrate Animals used for Experimental and Other Scientific Purposes and the Law of Ukraine "On the protection of animals against cruel treatment".

Organs were homogenized using Potter-Elvehjem homogenizer at $4{ }^{\circ} \mathrm{C}$ in a ratio of $1 \mathrm{~g}$ of tissue in $5 \mathrm{ml}$ of homogenization solution. For homogenization were used such solutions: sucrose $(250 \mathrm{mM})$ - for brain and testis [6], $\mathrm{KCl}(250 \mathrm{mM})$ - for thigh muscle [20], solution consisting of $250 \mathrm{mM}$ sucrose, $1 \mathrm{mM}$ EGTA, $10 \mathrm{mM}$ HEPES (pH 7.2) - for liver [12]. The homogenates were centrifuged for $15 \mathrm{~min}$ at 2,000 g. The supernatant was discarded and activity of superoxide dismutase with nitroblue tetrazolium $\left(\lambda_{\text {abs }}=540 \mathrm{~nm}\right.$; $\mathrm{UI} / \mathrm{mg}$ of protein) [5]; glutathione peroxidase - with Elman reagent $\left(\lambda_{\text {abs }}=412 \mathrm{~nm}\right.$; $\mu \mathrm{mol}$ $\mathrm{GSH} / \mathrm{min} \times \mathrm{mg}$ of protein) [18]; catalase - with ammonium molibdate and hydrogen peroxide ( $\lambda_{\text {abs }}=410 \mathrm{~nm} ; \mu \mathrm{mol} \mathrm{H}_{2} \mathrm{O}_{2} /$ min $\times \mathrm{mg}$ of protein) [15]; glucose-6-phosphate dehydrogenase - with $\mathrm{NADP}^{+}\left(\lambda_{\text {abs }}=520 \mathrm{~nm}\right.$; nmol of $\mathrm{NADPH} / \mathrm{min} \times \mathrm{mg}$ of protein) were measured [13]. Peroxidation product content (TBA-active products, TBA; $\mu \mathrm{mol} / \mathrm{mg}$ of protein) was measured with use of phosphorwolframic and thiobarbituric acids according to S. N. Korabieynikova [15]. Protein content in tissues was measured by Lowry method at $\lambda_{\text {abs }}=750 \mathrm{~nm}$ [17]. Ratio of antioxidant enzymes activity to content TBA (AOD/TBA), relation of superoxide dismutase and catalase activities (SOD/CAT) and ratio of glutathione peroxidase activity and catalase were calculated (GPO/CAT). All results concerning antioxidant ratios were expressed in relative units - r.u. [7]. Statistical analysis was carried out as described by M. P. Derkach [5].

\section{RESULTS AND DISCUSSION}

Liver is a central organ of taurine metabolism [16]. That is why we studied influence of per oral injection of this compound on hepatocyte antioxidant defense as one of integral indexes of its functional activity, physiological state and cell stress tolerance. It was determined that in liver tissue of I experimental group activity of superoxide dismutase increased on $52.5 \%$, and in rats of II experimental group value of the index did not differ from control group (see Table).

Glutathione peroxidase activity in liver tissue of both experimental groups increased proportionally to increase in taurine concentration - correspondingly on 50.0 and $75.0 \%$ comparing to control group. Analogically, catalase activity in I and II experimental groups was higher on 46.2 and $50.0 \%$, than in control animals. In animals of I experimental group activity of glucose-6-phosphate dehydrogenase increased on $47.1 \%$, that points on necessity in fast glutathione reduction and state of moderate oxidative stress [3]. Despite the increase of antioxidant defense enzymes activity, in both experimental groups, content of TBA-active products increased on 100.0 and $142.8 \%$, comparing to control. AOD/TBA ratio did not change in liver of both experimental groups animals. Decrease on $38.1 \%$ of SOD/CAT relation in animals of II experimental group, may indicate that cells counter with high concentrations of $\mathrm{H}_{2} \mathrm{O}_{2}$, and the increase of GPO/CAT ratio on $15.2 \%$, points on possible increase in glutathione production. This correlates with literature, showing that taurine addition to incubation medium increased glutathione levels [6].

Taurine in liver of both experimental groups led to oxidative stress which was partly compensated by increase in antioxidant defense enzyme activity in animals of I experimental group. Liver of II experimental group rats was exposed to high taurine concentra-

ISSN 1996-4536 (print) • ISSN 2311-0783 (on-line) • Біологічні Студії / Studia Biologica • 2015 • Том 9/№2 • С. 59-70 


\section{Antioxidant defense and content of TBA-active products in rat organs after long-term per oral injection of taurine, $\mathrm{M} \pm \mathrm{m}$}

Антиоксидантний захист органів щурів і вміст ТБК-активних продуктів за тривалого перорального введення таурину, $\mathrm{M} \pm \mathbf{m}$

\begin{tabular}{|c|c|c|c|c|}
\hline \multirow{2}{*}{ Tissue } & \multirow{2}{*}{ Indexes } & \multirow{2}{*}{$\begin{array}{c}\text { Control, } \\
n=3\end{array}$} & \multicolumn{2}{|c|}{ Taurine injection } \\
\hline & & & $\mathrm{I}, \mathrm{n}=5$ & $\mathrm{II}, \mathrm{n}=3$ \\
\hline \multirow{8}{*}{ Liver } & SOD, Ul/mg of protein & $0.59 \pm 0.12$ & $0.90 \pm 0.18^{*}$ & $0.54 \pm 0.10^{2}$ \\
\hline & $\mathrm{GPO}, \mu \mathrm{mol} \mathrm{GSH} / \mathrm{min} \times \mathrm{mg}$ of protein & $0.12 \pm 0.02$ & $0.18 \pm 0.02^{* *}$ & $0.21 \pm 0.01^{\# \#+\& \&}$ \\
\hline & CAT, $\mu \mathrm{mol} \mathrm{H}_{2} \mathrm{O}_{2} / \mathrm{min} \times \mathrm{mg}$ of protein & $0.26 \pm 0.02$ & $0.38 \pm 0.04^{* *}$ & $0.39 \pm 0.02^{\# \#}$ \\
\hline & G-6-P DG, nmol NADPH/min $\times m g$ of protein & $1.04 \pm 0.04$ & $1.53 \pm 0.11^{*}$ & $1.18 \pm 0.10$ \\
\hline & TBA, $\mu \mathrm{mol} / \mathrm{mg}$ of protein & $0.07 \pm 0.01$ & $0.14 \pm 0.03^{\star *}$ & $0.17 \pm 0.02^{\# \#}$ \\
\hline & AOD/TBA, r.u. & $0.07 \pm 0.01$ & $0.12 \pm 0.03$ & $0.08 \pm 0.01$ \\
\hline & SOD/CAT, r.u. & $0.63 \pm 0.04$ & $0.55 \pm 0.02$ & $0.39 \pm 0.06^{\#}$ \\
\hline & GPO/CAT, r.u. & $0.46 \pm 0.02$ & $0.44 \pm 0.01$ & $0.53 \pm 0.01^{\# \&}$ \\
\hline \multirow{8}{*}{$\begin{array}{l}\text { Thigh } \\
\text { muscle }\end{array}$} & SOD, Ul/mg of protein & $0.70 \pm 0.27$ & $1.11 \pm 0.34^{*}$ & $0.97 \pm 0.13^{\#}$ \\
\hline & $\mathrm{GPO}, \mu \mathrm{mol} \mathrm{GSH} / \mathrm{min} \times \mathrm{mg}$ of protein & $0.20 \pm 0.02$ & $0.32 \pm 0.02^{* * *}$ & $0.31 \pm 0.01^{\# \#}$ \\
\hline & CAT, $\mu \mathrm{mol} \mathrm{H}_{2} \mathrm{O}_{2} / \mathrm{min} \times \mathrm{mg}$ of protein & $0.47 \pm 0.04$ & $0.61 \pm 0.09^{*}$ & $0.61 \pm 0.07^{\#}$ \\
\hline & G-6-P DG, nmol NADPH/min $\times m g$ of protein & $0.55 \pm 0.02$ & $1.75 \pm 0.18^{*}$ & $1.44 \pm 0.25$ \\
\hline & TBA, $\mu \mathrm{mol} / \mathrm{mg}$ of protein & $0.08 \pm 0.02$ & $0.24 \pm 0.07^{\star *}$ & $0.15 \pm 0.05^{\# \&}$ \\
\hline & AOD/TBA, r.u. & $0.66 \pm 0.05$ & $0.63 \pm 0.09$ & $1.23 \pm 0.32$ \\
\hline & SOD/CAT, r.u. & $1.24 \pm 0.07$ & $1.33 \pm 0.09$ & $1.60 \pm 0.13$ \\
\hline & GPO/CAT, r.u. & $0.43 \pm 0.01$ & $0.55 \pm 0.03^{*}$ & $0.50 \pm 0.02$ \\
\hline \multirow{8}{*}{ Testes } & SOD, UI/mg of protein & $0.23 \pm 0.04$ & $0.27 \pm 0.08$ & $0.60 \pm 0.10^{\# \& \& \&}$ \\
\hline & $\mathrm{GPO}, \mu \mathrm{mol} \mathrm{GSH} / \mathrm{min} \times \mathrm{mg}$ of protein & $0.16 \pm 0.04$ & $0.24 \pm 0.03^{* *}$ & $0.30 \pm 0.01^{\# \#+2 \&}$ \\
\hline & CAT, $\mu \mathrm{mol} \mathrm{H}_{2} \mathrm{O}_{2} / \mathrm{min} \times \mathrm{mg}$ of protein & $0.38 \pm 0.04$ & $0.39 \pm 0.02$ & $0.57 \pm 0.01^{\# \# \& \&}$ \\
\hline & G-6-P DG, nmol NADPH/min $\times m g$ of protein & $1.20 \pm 0.22$ & $1.39 \pm 0.14$ & $1.44 \pm 0.23$ \\
\hline & TBA, $\mu \mathrm{mol} / \mathrm{mg}$ of protein & $0.03 \pm 0.01$ & $0.23 \pm 0.05^{* *}$ & $0.13 \pm 0.03^{\# \# \& \&}$ \\
\hline & AOD/TBA, r.u. & $0.42 \pm 0.06$ & $0.09 \pm 0.003^{\star * \star}$ & $0.75 \pm 0.04^{\# \#}$ \\
\hline & SOD/CAT, r.u. & $0.59 \pm 0.04$ & $0.61 \pm 0.07$ & $1.05 \pm 0.11^{\# \&}$ \\
\hline & GPO/CAT, r.u. & $0.42 \pm 0.05$ & $0.61 \pm 0.04^{*}$ & $0.52 \pm 0.02$ \\
\hline \multirow{8}{*}{ Brain } & SOD, Ul/mg of protein & $1.08 \pm 0.24$ & $1.21 \pm 0.30$ & $1.37 \pm 0.10$ \\
\hline & $\mathrm{GPO}, \mu \mathrm{mol} \mathrm{GSH} / \mathrm{min} \times \mathrm{mg}$ of protein & $0.18 \pm 0.04$ & $0.28 \pm 0.02^{\star *}$ & $0.25 \pm 0.01^{\# \&}$ \\
\hline & CAT, $\mu \mathrm{mol} \mathrm{H}_{2} \mathrm{O}_{2} / \mathrm{min} \times \mathrm{mg}$ of protein & $0.18 \pm 0.03$ & $0.38 \pm 0.03^{* *}$ & $0.55 \pm 0.04^{\# \# 2 \& \& 8}$ \\
\hline & G-6-P DG, nmol NADPH/min $\times m g$ of protein & $2.08 \pm 0.31$ & $3.22 \pm 0.15^{*}$ & $2.17 \pm 0.18$ \\
\hline & TBA, $\mu \mathrm{mol} / \mathrm{mg}$ of protein & $0.14 \pm 0.03$ & $0.13 \pm 0.03$ & $0.12 \pm 0.04$ \\
\hline & AOD/TBA, r.u. & $0.10 \pm 0.03$ & $0.27 \pm 0.04^{*}$ & $0.66 \pm 0.13^{\#}$ \\
\hline & SOD/CAT, r.u. & $1.92 \pm 0.29$ & $0.98 \pm 0.20^{*}$ & $1.00 \pm 0.08^{\#}$ \\
\hline & GPO/CAT, r.u. & $1.02 \pm 0.09$ & $0.76 \pm 0.06^{*}$ & $0.46 \pm 0.02^{\# \#}$ \\
\hline
\end{tabular}

Comments: SOD - superoxide dismutase, GPO - glutathione peroxidase, CAT- catalase, G-6-P DG - glucose-6-phosphate dehydrogenase, I - first experimental group, II - second experimental group, * - statistically significant differences between control group and I group, \# - between control group and II group, \& - between groups I and II (* $\mathrm{P}<0.05$; ${ }^{* *} \mathrm{P}<0.01$; ${ }^{* * *} \mathrm{P}<0.001$; ${ }^{*} \mathrm{P}<0.05$; \# $\mathrm{P}<0.01$; \#\# $\mathrm{P}<0.001$; \& $\mathrm{P}<0.05$; \&\& $\mathrm{P}<0.01$; \&\&\& $\mathrm{P}<0.001$ ).

Примітки: СОД - супероксиддисмутаза, ГПО - глутатіонпероксидаза, КАТ- каталаза, Г-6-ФДГ - глюкозо-6-фоссратдегідрогеназа, I - перша дослідна група, II - друга дослідна група, * - статистично достовірна різниця між показниками тварин I дослідної та контрольної групи, \# II дослідної та контрольної групи, \& - I та II дослідних груп ( ${ }^{*} \mathrm{P}<0,05$; ${ }^{* *} \mathrm{P}<0,01 ;$ *** $\mathrm{P}<0,001$; \# $P<0,05$; \# $\mathrm{P}<0,01$; \#\# $\mathrm{P}<0,001$; \& $\mathrm{P}<0,05$; \&\& $\mathrm{P}<0,01$; \&\& $\mathrm{P}<0,001)$. 
tion that leads to an acute increase in lipid peroxidation and accumulation of hydrogen peroxide and hydroxyl anion. An increase in hydrogen peroxide and hydroxyl anion concentration inhibit activity of superoxide dismutase, and activity of glutathione peroxidase is higher not only comparing to control, but, also comparing to I experimental group.

Skeletal striated muscle is a tissue that has a great necessity in ATP produced by mitochondria. It was shown that oral administration of $1 \%$ taurine solution in drinking water to rats increased the distance that animals can run, their endurance and decreased time during which the distance was ran through. This effect was triggered by an increase in electron transport through the respiration chain, and faster ATP synthesis [25]. However, this may involve increase of free oxygen radicals concentration.

Indeed, in thigh muscle of both experimental groups content of TBA-active products was increased. The highest concentration was found in animals of I experimental group - $200.0 \%$ higher than in control (see Table). In animals of II experimental group, content of TBA-active products was on $87.5 \%$ higher comparing with control. Because of oxygen free radicals growth in thigh muscle of both experimental groups, the activity of antioxidant defense enzymes and glucose-6-phosphate dehydrogenase increased. In $I^{\text {st }}$ experimental group GPO/CAT ratio increased.

Received data suggest that injection of taurine increased production of free radicals of oxygen, and despite of the enzymatic antioxidant defense link activity growth, it did not provide their utilization in muscle tissue.

Testes - gonads of male mammals that are characterized by high level of reaction to oxygen free radicals. With increase of their concentration in tissue, DNA of spermatozoa, their organelles are destroyed, and even spermatogenesis is violated [11]. Because of this, it is vital to support antioxidant defense in testes. Taurine is determined in high concentrations in testes, and it shows a dose-dependent antioxidant effect on spermatozoa [11]. That is why, we studied influence of per oral injection of taurine on antioxidant defense enzymes activity and content of lipid peroxidation products in rat testes.

Differently from liver, in testes of $\mathrm{I}^{\text {st }}$ experimental group animals per oral injection of taurine caused an increase in glutathione peroxidase activity (see Table). Activity of other antioxidant defense enzymes did not differ from that in control group. Additionally, TBA-active products content was 8 times higher comparing with control. AOD/TBA ratio also pointed negative impact of increase in taurine concentration - in I experimental group resistance to oxygen free radicals decreased in five times. Such decrease in resistance to oxygen free radicals can be explained by overproduction of hydroxyl anion, increased ratio GPO/CAT on $31.1 \%$ also pointed on it.

In animals of IInd experimental group, activity of antioxidant defense enzymes increased. Though content of TBA-active products was in three times higher than in control, it is lower on $177.0 \%$ than in I experimental group animals. Increase in activity of antioxidant defense enzymes lead to higher AOD/TBA ratio, more than two times, comparing with control. That indicated a rise of organism's resistance to stress, which was induced by an increase in taurine concentration. Increase of SOD/CAT ratio on $78.0 \%$ in testes of II experimental group animals indicated high production of superoxide anion and increase in hydrogen peroxide utilization by glutathione peroxidase.

Thus, in testes of animals of I experimental group, an increase in hydroxyl anion production and insufficient activity of antioxidant defense enzymes in cytosol caused an increase in TBA-active products content. In rat testes of II experimental group, processes of oxygen free radicals $\left(\mathrm{O}_{2}^{--}, \mathrm{OH}^{-}, \mathrm{H}_{2} \mathrm{O}_{2}\right)$ production were activated. This led to activation of antioxidant enzymes - superoxide dismutase, glutathione peroxidase and mostly

ISSN 1996-4536 (print) • ISSN 2311-0783 (on-line) • Біологічні Студії / Studia Biologica • 2015 • Том 9/№2 • С. 59-70 
catalase. Herewith TBA-active products content was lowered comparing with I experimental group. It is possible that the effect of per oral injection of taurine in experimental groups is implemented by different mechanisms.

El Idrissi [6] showed, that taurine maintains neuron integrity and saves functional activity of mitochondria on physiological level. However, realization mechanism of such effect of taurine on neurons in not clearly understood, though scientists assume that it may be connected to antioxidant effect of taurine.

As in liver tissue of I experimental group animals, in brain of both experimental groups the activity of antioxidant defense enzymes increased but TBA-active products concentration stayed at control level. Because of this, increased AOD/TBA ratio (in 1.8 and 5.8 times, correspondingly), which indicates an increase in brain resistance to oxygen free radicals.

Thus, per oral injection of taurine caused activation of antioxidant defense enzymatic link in rat brain that is an evidence of increase in oxygen active forms production. Herewith, an increase of glutathione peroxidase and catalase provide effective antioxidant protection of neurons that keeps the contents of TBA-active products within control. Since taurine plays a role as nervous system activator [16], an increase in antioxidant defense enzymes is a probable reaction on an increase of metabolic processes in neurons. Though it is more possible that taurine causes growth of oxygen free radicals concentration (hydrogen peroxide and hydroxyl anion), but enzymatic activity is sufficient for their utilization in this tissue.

To study of antioxidant role of taurine as universal detoxicant and substance that reduces the content of oxygen free radicals numerous studies are devoted [21-23, 26]. But there are few works that show an effect of per oral animal treatment by taurine on the antioxidant system of tissues and organs. Our studies show that activity of enzymes depends on taurine dose and type of tissue target.

After injection directly into the gastrointestinal tract, taurine is absorbed in the organism. The first organ that is exposed to this compound is liver. Determined increase in activity of antioxidant defense enzymes and TBA-active products concentration in liver tissues indicated a rise of oxygen free radicals and destruction of structural components of hepatocyte membranes (Fig. 1, A). In animals of I experimental group activity of antioxidant defense enzymes increased. This allows to assume that taurine causes increased production of superoxide anion (Fig. 2). Taurine is involved in synthesis of components of the respiratory chain [24], and with increase of taurine concentration, increases content of complex I and III proteins, and activition of electron transporting chain takes place. Intensification of electron transport in the respiratory chain leads to an increase in oxygen free radicals, and this activates antioxidant enzymes [23].

In liver of animals of II experimental group, superoxide dismutase activity was on control level, and catalase, glutathione peroxidase and TBA-active products concentration increased, that indicates mechanism of oxygen free radicals production that differs from I experimental group. Namely, an increased formation of hydroxyl anion and hydrogen peroxide (see Fig. 2) that is accompanied by peroxidation of unsaturated fatty acids and lipoprotein complexes. Other results were obtained under rat detoxification of iron and arsenic - taurine supported their removal [22]. However, according to these authors, long term (for four weeks) administration of taurine had no effect on the antioxidant defense of three-month rat liver [22]. Study of the antioxidant-prooxidant influence of taurine on 20-22 months old rats showed a decrease in glutathione peroxidase activity and an increase in concentration of TBA-active products in liver [21].

ISSN 1996-4536 (print) • ISSN 2311-0783 (on-line) • Біологічні Студії / Studia Biologica • 2015 • Том 9/№2 • C. 59-70 

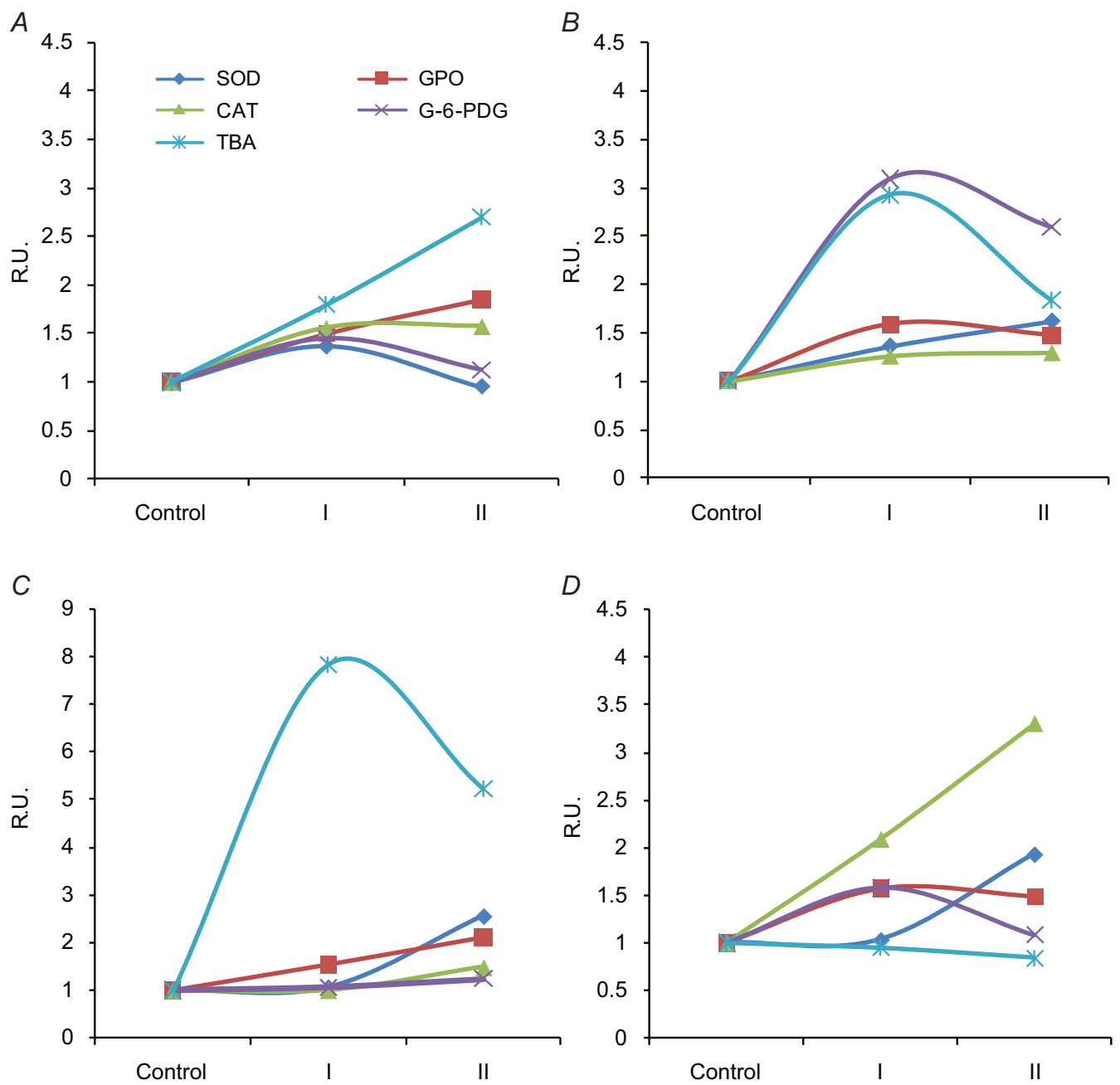

Fig. 1. Normalized indices of antioxidant enzymes, glucose-6-phosphate dehydrogenase and TBA-active products content: $A$ - liver; $B$ - thigh muscle; $C$ - testes; $D$ - brain

Рис. 1. Нормалізовані показники активностей ензимів антиоксидантного захисту, глюкозо-6-сросфатдегідрогенази та ТБК-активних продуктів: $A$ - печінка; $B$ - м'язи; $C$ - сім'яники; $D$ - мозок

A lack of taurine in muscle tissue leads to mitochondrial illnesses (lactic acidosis, mitochondrial myopathy, ect.) and oxidative stress [23]. However, based on our research, the surplus of taurine also negatively affects tissue antioxidant defense (see Fig. 1, B). In rat muscle tissue of animals that were given $3 \%$ taurine water solution instead of drinking water during 30 days, products of lipid peroxidation also increased [3]. Such data indicate dose dependent action of taurine that is realized by different mechanisms. In animals of I experimental group administration of taurine caused an increase in production of hydrogen peroxide, that may be explained by activation of peroxidases. While, in II experimental group, taurine caused a rise of superoxide anion formation which may be triggered by activation of respiration chain or xanthine oxidase.

ISSN 1996-4536 (print) • ISSN 2311-0783 (on-line) • Біологічні Студії / Studia Biologica • 2015 • Том 9/№2 • C. 59-70 
Glutathione peroxidase is the only enzyme which can utilize hydroxyl anion. That is why, the detected increase in activity of glutathione peroxidase and the increase of TBA-active products content in testes tissue of I experimental group may indicate an increased production of hydroxyl anion (see Fig. 2). Also, an increase in concentration of lipid peroxidation products might point on the insufficient activity of glutathione peroxidase to utilize oxygen free radicals. These changes can lead to DNA and membrane damage, occurrence of genetic abnormalities and reduce fertilizing ability or cause infertility [11]. In testes of animals of II experimental group, superoxide dismutase and catalase activities are elevated, indicating on stimulation of not only hydrogen peroxide and hydroxyl anion radical formation, but also on an increased superoxide anion formation (see Fig. 2). A reduction of TBA-active products content in II experimental group compared to I, indicates the activation of antioxidant defense system, but this stimulation is not sufficient enough to return the lipid peroxidation to control level. Probably, taurine in testes shows prooxidative properties. In contrast to these results, a dose of $150 \mathrm{mg} / \mathrm{kg}$ of taurine which was injected to three months immature rats during 4 weeks, the activity of antioxidant protection enzymes did not significantly change, but spermatozoa had higher mobility viability and lower percentage of the abnormal cells. In addition, taurine caused a partial recovery of antioxidant defense activity in rat testes by simultaneous administration with pro-oxidant doxorubicin [2].

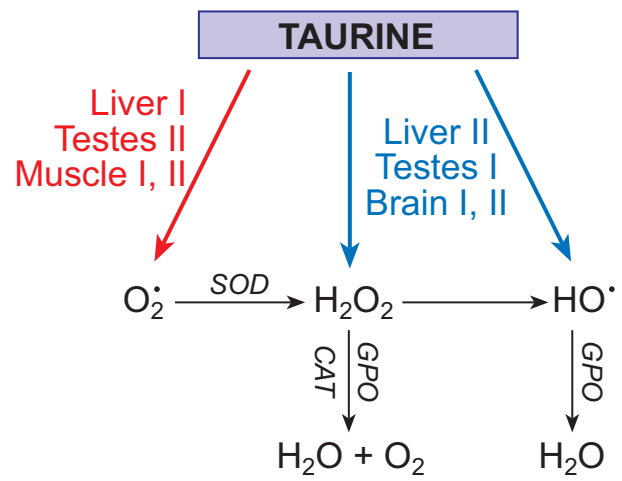

Fig. 2. Scheme of taurine influence on production of oxygen free radicals

Рис. 2. Схема впливу таурину на продукцію вільних радикалів оксигену

In rat brain of both experimental groups, the activity of glutathione peroxidase and catalase increased (see Fig. 2), maintaining effective utilization of oxygen free radicals - the TBA-active products content was on control levels (see Fig. 1, D). Different results were obtained when taurine was added to drinking water ( $2 \%$ solution) to rats 20-22 month old: activity of antioxidant defense enzymes decreased [21]. When neurons were incubated with taurine, the activity of glutathione peroxidase increased. This increase of enzyme activity may be connected with the ability to increase glutathione reduction in neurons [16].

Thus, the effect of per oral injection of taurine on antioxidant defense enzymes is tissue- and dose-dependent. Injection of taurine caused a rise in lipid peroxidation activity in all investigated tissues, and accumulation of TBA-active products there, excluding brain. 
1. Chou Ch., Lin H., Hwang L. Taurine resumed neuronal differentiation in arsenitetreated N2a cells through reducing oxidative stress, endoplasmic reticulum stress, and mitochondrial dysfunction. Am. Ac, 2015; 47(4): 735-44.

2. Das J., Ghosh J., Manna P. et al. Taurine protects rat testes against doxorubicin-induced oxidative stress as well as p53, Fas and caspase 12-mediated apoptosis. Am. Ac, 2012; 42: 1839-1855.

3. Dawson R., Biasetti M., Messina S. et al. The cytoprotective role of taurine in exerciseinduced muscle injury. Am. Ac, 2002; 22: 309-324.

4. Derkach M. P., Gumenizkiy R. Ya., Chaban M. E. Course of variational statistics. Kyiv: High School, 1977. 210 p. (In Ukrainian).

5. Dubinina E. E. Salnicova L. Ya., Yefimova L. F. Activity and izozyme spectrum of superoxide dismutase of erythrocytes. Lab. Work, 1983; 10: 30-33. (In Russian).

6. El Idrissi A. Taurine increases mitochondrial buffering of calcium: role in neuroprotection. Am. Ac, 2008; 34(2): 321-328.

7. Haan J.B., Cristiano F., lannello R.C. et al. Cu/Zn-superoxide dismutase and glutathione peroxidase during aging. Biochem. Mol. Biol. Intern, 1995; 5(6):1281-1297

8. Hagar H.H. The protective effect of taurine against cyclosporine A-induced oxidative stress and hepatotoxicity in rats. Tox. Let, 2004; 151: 335-343.

9. Hansen S., Birkedal H., Wibrand F. Taurine and regulation of mitochondrial metabolism. Adv. Exp. Med. Bio, 2015; 883(1): 397-405.

10. Iwasaki A., Gagnon C. Formation of reactive oxygen species in spermatozoa of infertile men. Fertil. Steril, 1992; 57: 409-418.

11. Jang J., Zong $X$., Wu G. et al. Taurine increases testicular function in aged rats by inhibiting oxidative stress and apoptosis. Am. Ac, 2015. (In print).

12. Kondrashova M. N. Transaminase cycle of substrate oxidation in cell, as an adaptation mechanism to hypoxia. Pharm. Corr. Hypox. Stat. 1989; 1: 51-70. (In Russian).

13. Kamishnikov V.S. Handbook of clinical and biochemical studies and laboratory diagnosis. Moscow: MEDpress-inform, 2004. 459 p. (In Russian).

14. Korabieynikova S.N. Modification of the definition of lipid peroxidation method reaction with TBA. Lab. Work, 1989; 7: 8-10. (In Russian).

15. Korolyuk M.A., Ivanova L.I., Mayorova I.G. et al. The method for determining the activity of catalase. Lab. Work, 1983; 10: 16-18. (In Russian).

16. Lambert I.H., Kristensen D.M., Holm J.B. Physiological role of taurine - from organism to organelle. Acta Physiol, 2015; 213: 191-212.

17. Lowry O.H., Rosebrough N.J., Fair A.L. et al. Protein measurement with Folin phenol reagent. J. Biol. Chem, 1951; 193: 264-275.

18. Moin V.M. A simple and specific method for determining the activity of glutathione peroxidase in erythrocytes. Lab. Work, 1986; 12: 724-727. (In Russian).

19. Ortenblad N., Young J. F., Oksbjerg N. et al. Reactive oxygen species are important mediators of taurine release from skeletal muscle cells. Am. J. Physiol. Cell. Physiol, 2003; 284: 1362-1373.

20. Palmi M., Youmbia G. T., Fusia F. et al. Potentiation of mitochondrial $\mathrm{Ca}^{2+}$ sequestration by taurine. Biochem. Pharm, 1999; 58: 1123-1131.

21. Parildar-Karpuzoð H., Mehmetçik G., Özdemirler-Erata G. et al. Effect of taurine treatment on pro-oxidant-antioxidant balance in livers and brains of old rats. Pharmac. Rep, 2008; 60: 673-678.

22. Pop-Busui R., Sullivan K. A., Van Huysen C. et al. Depletion of taurine in experimental diabetic neuropathy: implications for nerve metabolic, vascular, and functional deficits. Exp. Neur, 2001; 168: 259-272.

23. Schaffer S.W., Azuma J., Mozzafari M. Role of antioxidant activity of taurine in diabetes. J. Physiol. Pharmacol, 2009; 87: 91-99. 
24. Suzuki T., Suzuki T., Wada T. et al. Novel taurine-containing uridine derivatives and mitochondrial human diseases. Nucl. Ac. Res. Suppl, 2001; 1: 257-258.

25. Yatabe Y., Miyakawa S., Miyazaki T. et al. Effects of taurine administration in rat skeletal muscles on exercise. J. Orthop. Sci, 2003; 8: 415-419.

26. Young I.S., Woodside J.V. Antioxidants in health and disease. J. Clin. Pathol, 2001; 54: 176-186.

\title{
АНТИОКСИДАНТНИЙ ЗАХИСТ ОРГАНІЗМУ ЩУРІВ ЗА ТРИВАЛОГО ПЕРОРАЛЬНОГО ВВЕДЕННЯ ТАУРИНУ
}

\author{
Р. Д. Остапів ${ }^{1,2}$, В. В. Манько \\ ${ }^{1}$ Львівський національний університет імені Івана Франка \\ вул. Грушевського, 4, Львів 79005, Україна \\ ${ }^{2}$ ДНДКІ ветеринарних препаратів та кормових добавок \\ вул. Донецька, 11, Львів 79019, Україна \\ e-mail:vvmanko@Inu.edu.ua
}

Метою роботи було вивчити активність ензиматичної ланки антиоксидантного захисту, активність глюкозо-6-фоосфатдегідрогенази та вміст продуктів перекисного окиснення ліпідів за перорального введення таурину. Самців щурів лінії Wistar масою 190-220 г і віком 4,5 місяця, ділили на три групи - контрольну, тваринам якої протягом 28 діб щоденно вводили у стравохід питну воду, та дві дослідні, яким вводили розчин таурину з розрахунку 40 (І дослідна група) і 100 (II дослідна група) мг/кг маси, відповідно. Після завершення досліджень тварин декапітували під легким хлороформним наркозом і виділяли тканини печінки, мозку, сім'яника та стегнового м'яза. Тканини гомогенізували, центрифугували при $1000 \mathrm{~g}$ і в супернатанті визначали активність супероксиддисмутази, глутатіонпероксидази, каталази, глюкозо-6-фросфратдегідрогенази та вміст ТБК-активних продуктів. Розраховували відношення активностей ензимів антиоксидантного захисту до вмісту ТБК-активних продуктів - АОЗ/ТБК.

Виявлено, що у печінці тварин І дослідної групи зростає активність усіх ензимів антиоксидантного захисту, глюкозо-6-фосфатдегідрогенази та вміст ТБК-активних продуктів. За таких умов зростає опірність тканини вільним радикалам оксигену, на що вказує збільшення відношення АОЗ/ТБК. У II дослідній групі активність супероксиддисмутази повертається до контрольних значень, проте інші показники залишаються вищими за контроль. Подібна тенденція спостерігається у стегновому м'язі тварин обох дослідних груп, де зростає як активність ензимів антиоксидантного захисту і глюкозо-6-фросфатдегідрогенази, так і вміст продуктів перекисного окиснення ліпідів. При цьому відношення АОЗ/ТБК є найвищим у тварин II дослідної групи. У сім'яниках тварин I дослідної групи зростає активність глутатіонпероксидази, однак вміст ТБК-активних продуктів $є$ найвищим. Це зумовлює зниження коефріцієнта АОЗ/ТБК більш ніж у 4 рази. У II дослідній групі зі зростанням ензиматичної активності антиоксидантного захисту вміст ТБК-активних продуктів знижується, порівняно з І дослідною групою, відповідно зростає і відношення АОЗ/ ТБК. У тканині мозку активності глутатіонпероксидази та каталази зростали у разі незмінного вмісту продуктів перекисного окиснення ліпідів. Це зумовлює зростання відношення АОЗ/ТБК, яке вказує на збільшення опірності організму вільним радикалам оксигену.

ISSN 1996-4536 (print) • ISSN 2311-0783 (on-line) • Біологічні Студії / Studia Biologica • 2015 • Том 9/№2 • C. 59-70 
Отже, вплив перорального введення таурину на антиоксидантний захист тканин щурів $є$ дозозалежним і тканиноспецифічним.

Ключові слова: таурин, супероксиддисмутаза, глутатіонпероксидаза, каталаза, ТБК-активні продукти, печінка, стегновий м'яз, сім'яники, мозок.

\title{
АНТИОКСИДАНТНАЯ ЗАЩИТА ОРГАНИЗМА КРЫС ПРИ ДЛИТЕЛЬНОМ ПЕРОРАЛЬНОМ ВВЕДЕНИИ ТАУРИНА
}

\author{
Р. Д. Остапив ${ }^{1,2}$, В. В. Манько \\ ${ }^{1}$ Львовский национальный университет имени Ивана Франко \\ ул. Грушевского, 4, Львов 79005, Украина \\ ${ }^{2}$ ГНИКИ ветеринарных препаратов и кормовых добавок \\ ул. Донецкая, 11, Львов 79019, Украина \\ e-mail:vvmanko@Inu.edu.ua
}

Целью работы было изучить активность энзиматического звена антиоксидантной защиты, активность глюкозо-6-фросфратдегидрогеназы и содержание продуктов перекисного окисления липидов при пероральном введении таурина. Самцов крыс линии Wistar массой 190-220 г и возрастом 4,5 месяца делили на три группы - контрольную, животным которой в течение 28 суток ежедневно вводили в пищевод питьевую воду и две экспериментальные, которым вводили раствор таурина из расчета 40 (I экспериментальная группа) и 100 (II экспериментальная группа) мг/кг массы, соответственно. После завершения исследований животных декапитировали под легким хлороформным наркозом и выделяли ткани печени, мозга, семенника и бедренной мышцы. Ткани гомогенизировали, центрифугировали при 1000 g и в супернатанте определяли активность супероксиддисмутазы, глутатионпероксидазы, каталазы, глюкозо-6-фосфратдегидрогеназы и содержание ТБК-активных продуктов. Рассчитывали отношение активностей ферментов антиоксидантной защиты к содержимому ТБК-активных продуктов - АОЗ/ТБК.

Выявлено, что в печени животных I экспериментальной группы возрастает активность всех энзимов антиоксидантной защиты, глюкозо-6-фосфратдегидрогеназы и содержание ТБК-активных продуктов. При таких условиях возрастает сопротивляемость ткани свободным радикалам кислорода, на что указывает увеличение отношения АОЗ/ТБК. Во ІІ экспериментальной группе активность супероксиддисмутазы возвращается к контрольным значениям, однако другие показатели остаются выше контроля. Подобная тенденция наблюдается в бедренной мышце животных обеих экспериментальных групп, где возрастает как активность энзимов антиоксидантной защиты и глюкозо-6-фоосфатдегидрогеназы, так и содержание продуктов перекисного окисления липидов. При этом отношение АОЗ/ТБК является самым высоким у животных II экспериментальной группы. В семенниках животных I экспериментальной группы возрастает активность глутатионпероксидазы, однако содержание ТБК-активных продуктов является самым высоким. Это приводит к снижению коэффрициента АОЗ/ТБК более чем в 4 раза. Во II экспериментальной группе с повышением энзиматической активности антиоксидантной защиты содержание ТБК-активных продуктов снижается,

ISSN 1996-4536 (print) • ISSN 2311-0783 (on-line) • Біологічні Студії / Studia Biologica • 2015 • Том 9/№2 • С. 59-70 
по сравнению с I экспериментальной группой, соответственно возрастает и отношение АОЗ/ТБК. В ткани мозга активности глутатионпероксидазы и каталазы возрастали, при неизменном содержании продуктов перекисного окисления липидов. Это вызывает рост отношения АОЗ/ТБК, которое указывает на увеличение сопротивляемости организма свободным радикалам кислорода.

Следовательно, влияние перорального введения таурина на антиоксидантную защиту тканей крыс дозозависимое и тканеспецифическое.

Ключевые слова: таурин, супероксиддисмутаза, глутатионпероксидаза, каталаза, ТБК-активные продукты, печень, бедренная мышца, семенники, мозг.

Одержано: 08.07.2015 